\title{
Cost-effectiveness of Carbetocin versus Oxytocin for Prevention of Postpartum Hemorrhage Resulting from Uterine Atony in Women at high-risk for bleeding in Colombia
}

\section{Rendimento da carbetocina versus oxitocina para a prevenção da hemorragia pós-parto resultante da atonia uterina em mulheres com alto risco de sangramento na Colômbia}

\author{
Yaneth Gil-Rojas ${ }^{1}$ Pieralessandro Lasalvia ${ }^{1}$ Fabián Hernández ${ }^{1} \quad$ Camilo Castañeda-Cardona ${ }^{1}$ \\ Diego Rosselli \\ 1 NeuroEconomix, Bogota, Colombia \\ 2 Department of Clinical Epidemiology and Biostatistics, Facultad de \\ Medicina de la Pontificia Universidad Javeriana, Bogota, Colombia \\ Address for correspondence Diego Rosselli, Department of Clinical \\ Epidemiology and Biostatistics, Facultad de Medicina de La Pontificia \\ Universidad Javeriana, Carrera 7 No. 40-62, Bogota, Colombia \\ (e-mail: diego.rosselli@gmail.com). \\ Rev Bras Ginecol Obstet 2018;40:242-250.
}

\begin{abstract}
Keywords

- cost-effectiveness

- carbetocin

- oxytocin

- prevention postpartum hemorrhage

- pregnancy

- high-risk

Objective To assess the cost-effectiveness of carbetocin versus oxytocin for prevention of postpartum hemorrhage (PPH) due to uterine atony after vaginal delivery/ cesarean section in women with risk factors for bleeding.

Methods A decision tree was developed for vaginal delivery and another one for cesarean, in which a sequential analysis of the results was obtained with the use of carbetocin and oxytocin for prevention of PPH and related consequences. A third-party payer perspective was used; only direct medical costs were considered. Incremental costs and effectiveness in terms of quality-adjusted life years (QALYs) were evaluated for a one-year time horizon. The costs were expressed in 2016 Colombian pesos (1 USD = 3,051 Col\$).

Results In the vaginal delivery model, the average cost of care for a patient receiving prophylaxis with uterotonic agents was Col\$347,750 with carbetocin and Col\$262,491 with oxytocin, while the QALYs were 0.9980 and 0.9979 , respectively. The incremental costeffectiveness ratio is above the cost-effectiveness threshold adopted by Colombia. In the model developed for cesarean section, the average cost of a patient receiving prophylaxis with uterotonics was Col\$ 461,750 with carbetocin, and Col\$481,866 with oxytocin, and the QALYs were 0.9959 and 0.9926 , respectively. Carbetocin has lower cost and is more effective, with a saving of Col\$ 94,887 per avoided hemorrhagic event.

Conclusion In case of elective cesarean delivery, carbetocin is a dominant alternative in the prevention of PPH compared with oxytocin; however, it presents higher costs than oxytocin, with similar effectiveness, in cases of vaginal delivery.
\end{abstract}

received

November 28, 2017

accepted

April 4, 2018
DOI https://doi.org/

$10.1055 / \mathrm{s}-0038-1655747$.

ISSN 0100-7203.
Copyright (e) 2018 by Thieme Revinter

Publicações Ltda, Rio de Janeiro, Brazil
License terms

(c) $(1) \$$ 


\section{Resumo}

Palavras chave
- análise custo-
eficiência
- carbetocina
- oxitocina
- prevenção
- hemorragia pós-parto
- gravidez de alto risco

Objetivo Avaliar a relação custo-eficácia da carbetocina versus oxitocina para prevenção de hemorragia pós-parto (HPP) vaginal e cesariana devido à atonia uterina em mulheres com fatores de risco para desenvolver sangramento.

Métodos Foram desenvolvidos protocolos de manejo para parto vaginal e outra para parto por cesárea e analisados resultados obtidos com carbetocina e oxitocina na prevenção de HPP, assim como, consequências relacionadas à ocorrência do evento hemorrágico. A perspectiva utilizada foi a do terceiro pagador, portanto, apenas os custos médicos diretos foram levados em consideração. Os custos incrementais e a eficácia em termos de anos de vida ajustados pela qualidade (QALY) foram avaliados para um horizonte de tempo de um ano. Os custos foram expressos em pesos colombianos de 2016 ( 1 USD $=3.051$ Col\$).

Resultados No modelo de parto vaginal, o custo médio de cuidados para um paciente que recebeu profilaxia com agentes uterotônicos foi de Col\$347.750 com carbetocina e Col\$262.491 com oxitocina, enquanto os QALYs foram 0,9980 e 0,9979, respectivamente. $\mathrm{O}$ índice incremental de custo-efetividade está acima do limite de custoefetividade adotado pela Colômbia. No modelo desenvolvido para parto por cesárea, o custo médio do paciente que recebeu profilaxia com terapia uterotônica foi de Col\$ 461.750 com carbetocina e Col\$ 481.866 com oxitocina e os QALYs foram 0,9959 e 0,9926, respectivamente. A carbetocina foi a alternativa com menor custo e maior efetividade com uma economia de $\$ 94.887$ por evento hemorrágico evitado.

Conclusão A carbetocina no parto eletivo por cesárea é uma alternativa dominante na prevenção da PPH em relação à oxitocina; porém representa custos mais altos com uma eficácia similar à da oxitocina no caso de parto vaginal.

\section{Introduction}

Postpartum hemorrhage (PPH) is defined as a blood loss greater than $500 \mathrm{~mL}$ within 24 hours postpartum and is considered severe if the loss reaches $1,000 \mathrm{~mL}$ in the same time interval. ${ }^{1}$ Postpartum hemorrhage affects $\sim 2 \%$ of women in labor and it is responsible a quarter of maternal deaths. Uterine atony is the most common cause of this condition, but there may be others, such as genital trauma, uterine rupture, placental retention or maternal clotting disorders. The methods of active behavior during delivery, which include administration of prophylactic uterotonics after the birth of the newborn, early clamping and cutting of the umbilical cord, controlled traction of the cord, and uterine massage, have been associated with a considerable reduction in the frequency of $\mathrm{PPH} .^{1}$

Colombia has made progress in reducing maternal mortality by $25 \%$; however, there are still $\sim 400$ deaths per year associated with pregnancy and delivery. ${ }^{2}$ During 2012 , when surveillance for the event of extreme maternal morbidity was initiated, hemorrhagic complications ranked second, with 23.1\%. In 2013, 2014, 2015 and 2016, the proportions of cases of extreme maternal morbidity attributed to hemorrhagic complications were $20 \%, 20.2 \%, 18 \%$ and $14.5 \%$, respectively. ${ }^{3}$ Likewise, there has been a decline in the proportion of maternal deaths attributed to bleeding complications, reaching $13 \%$ in $2016 .^{3}$ These values show the impact of active behavior applied in the local context in reducing maternal morbidity and mortality attributed to PPH.

Uterotonic agents for prevention of PPH include oxytocin, methylergonovine, misoprostol and, more recently, carbetocin. Oxytocin is the most frequently used agent but, due to its short half-life, it must be administered by intravenous infusion for sustained uterotonic activity. Carbetocin has an efficacy and safety profile very similar to oxytocin and, due to its pharmacokinetic characteristics, has a longer uterotonic activity. ${ }^{4-6}$ According to the national guidelines, oxytocin is the uterotonic agent of choice in prevention; however, international guidelines like those from the Royal College of Obstetricians and Gynaecologists (RCOG) and the Society of Obstetricians and Gynaecologists of Canada (SOGC) already include carbetocin as an alternative, mainly in elective caesarean section. ${ }^{4-6}$

The objective of this evaluation was to estimate the incremental cost-effectiveness ratio of carbetocin compared with oxytocin for prevention of PPH by uterine atony in women with at least one risk factor for hemorrhage, from the perspective of the Colombian health system. Women with low risk for hemorrhage were not considered, since the indication for them is less clear. The study was based on the guidelines established in the manual for the elaboration of economic assessments in health proposed by the national Institute of Technology Assessment in Health (IETS). ${ }^{7}$ 


\section{Methods}

A cost-effectiveness analysis was developed from the perspective of the third-party payer to compare the use of carbetocin in the prevention of PPH with that of oxytocin in women with the presence of at least one risk factor for hemorrhage due to uterine atony. Among the risk factors described for PPH due to uterine atony are: multiple gestation, polyhydramnios, macrosomia, large multiparous, severe hydrocephalus, prolonged labor and chorioamnionitis. ${ }^{8}$ A model for vaginal delivery and another one for cesarean delivery are presented separately because the characteristics of these populations may change, as well as risk factors and response to interventions. The main outcome was prevention of PPH, defined as a blood loss exceeding $500 \mathrm{~mL} .{ }^{9}$ Also, as part of the sequential analysis, the consequences of the hemorrhagic event with each of the alternatives were considered, particularly the treatment of $\mathrm{PPH}$, use of additional uterotonics and the requirement of surgical intervention. Considering that there are several outcomes that measure the effectiveness of treatment (prevention of $\mathrm{PPH}$, use of additional uterotonics, adverse events), quality-adjusted life years (QALYs) were used as a common outcome. ${ }^{7}$ The time horizon considered in the economic evaluation was 1 year, so no discount rate was required.

\section{Decision Model}

The models were constructed from the review of previous studies, ${ }^{10-14}$ and were discussed and validated by a group of thematic experts. Two decision trees were developed with TreeAge Pro Suite 2009 (TreeAge Software Inc., Williamstown, MA, USA), one for cesarean section (-Fig. 1) and one

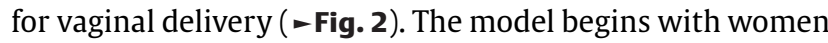
with the presence of at least one risk factor for PPH due to uterine atony who can receive prophylaxis with any of the technologies being evaluated: carbetocin or oxytocin. The first branch defines the occurrence or not of PPH (blood loss $>500 \mathrm{~mL}$ ), which corresponds to an analysis of the response to preventive interventions. Carbetocin is available as an injectable solution of $100 \mathrm{mcg} / \mathrm{mL}$ and is a drug for hospital use that should be administered in a single dose of $100 \mathrm{mcg}$ in both vaginal and cesarean deliveries. Oxytocin is available in an injectable solution of $5 \mathrm{IU} / \mathrm{mL}$ or $10 \mathrm{IU} / \mathrm{mL}$, and the recommended dose in cases of vaginal delivery is 5 to 10 IU, intramuscularly, but in case of cesarean section, an IV bolus of $5 \mathrm{IU}$ is recommended followed by an infusion of $30 \mathrm{IU}$.

Subsequently, sequential events that take place in the event of PPH occur until survival or death at hospital discharge and whether or not the recommended treatments are

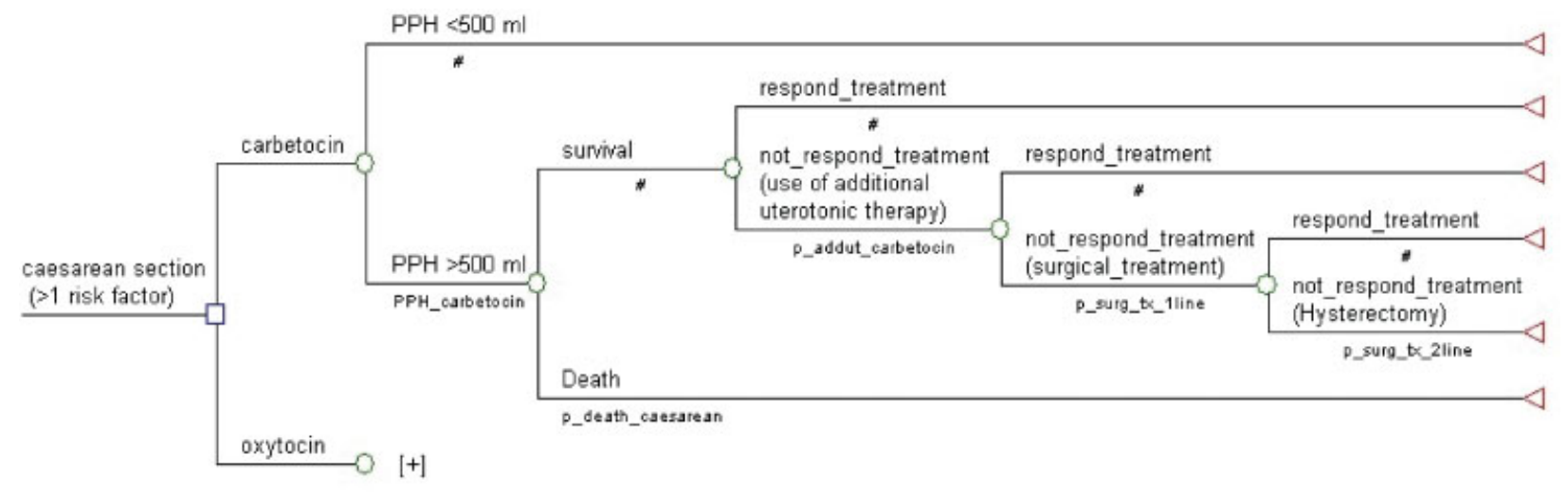

Fig. 1 Decision model in the analysis of PPH in cesarean section.

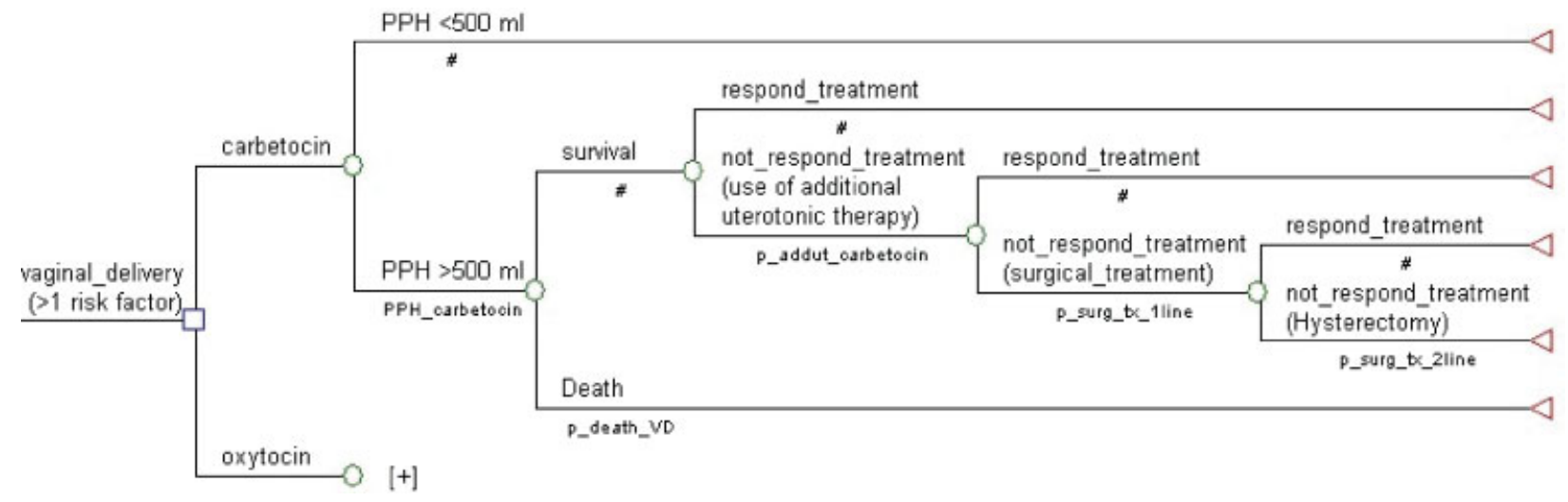

Fig. 2 Decision model in the analysis of PPH in vaginal delivery. 
given. If PPH is present, the patient is given a first line of treatment, and if no response is obtained, additional uterotonics are administered; if no response to the pharmacological treatment is obtained, a first surgical approach including uterine tamponade and/or hemostatic suture is performed. If the patient does not respond to this treatment, a second-line surgical procedure would be performed, which usually corresponds to hysterectomy.

\section{Costs}

Due to the perspective considered, only direct medical costs required to prevent and treat hemorrhagic events with each of the alternatives were taken into account. All costs were expressed in Colombian pesos in 2016. The resource identification was based on the information from clinical practice guidelines and that provided by a group of clinical experts.

We considered laboratories, procedures and hospital stay required in the process of care of a patient from the administration of carbetocin or oxytocin. If no PPH was present, the costs of the drugs administered in prevention and the hospital stay after vaginal delivery and cesarean section were considered. If the event was present, the costs of first and second line pharmacological treatments, and first and second line surgical approaches were considered. To obtain the cost of medications, the following sources were consulted: 2016 Report of the Drug Price Information System $\left(\right.$ SISMED) ${ }^{7}$ and official documents of price regulation for medicines issued by the Ministry of Health. ${ }^{15}$ The average price reported for a carbetocin ampoule of $100 \mathrm{mcg}$ was Col\$ 95,800 and that of the oxytocin ampoule of $10 \mathrm{IU}$ was Col\$
1,130 . The calculation of costs for procedures associated in particular with the treatment follow-up was performed with the Social Security Institute (ISS, in the Spanish acronym) Fee Manual (Agreement 256 of 2001), with a 30\% increase for the case base scenario. ${ }^{16}$ The prices of medical supplies, particularly surgical material, were obtained from the "Colombia Efficient Acquisition" (Secop I, in the Spanish acronym) portal. $^{17}$

Only the most frequently reported adverse events for carbetocin and oxytocin, which are nausea and vomiting, were considered in the model. The identification of resources required for the management of adverse reactions was performed with the assistance of a clinical expert. The costs of adverse events were included within the treatment costs, weighted by the frequency of presentation. The total costs in vaginal and cesarean deliveries for the compared alternatives are presented in -Tables $\mathbf{1}$ and $\mathbf{2}$, respectively.

\section{Effects}

The model parameters were obtained from randomized clinical trials comparing carbetocin with oxytocin, from local databases and expert consultation. The studies considered were identified from a panoramic review developed to evaluate the effectiveness and safety of carbetocin compared with other oxytocics in the prevention of $\mathrm{PPH}$.

To obtain information on mortality in patients with $\mathrm{PPH}$, several sources were consulted: the Individual Health Service Provision Registry (RIPS, in the Spanish acronym), ${ }^{18}$ vital statistics of National Administrative Department of Statistics (DANE, in the Spanish acronym), ${ }^{19}$ the National Public Health

Table 1 Total costs in the vaginal delivery model (base case)

\begin{tabular}{|l|l|l|}
\hline Group of patients & Carbetocin & Oxytocin \\
\hline No PPH & $\$ 183,245$ & $\$ 89,442$ \\
\hline PPH responding to the 1st line of pharmacological treatment & $\$ 1,426.303$ & $\$ 1,332.499$ \\
\hline PPH that respond to additional uterotonics & $\$ 109,843$ & $\$ 16,040$ \\
\hline PPH that respond to the first surgical approach & $\$ 472,038$ & $\$ 1,332.499$ \\
\hline PPH responding to hysterectomy & $\$ 1,310.406$ & $\$ 1,216.603$ \\
\hline Death & $\$ 231,494$ & $\$ 137,691$ \\
\hline
\end{tabular}

Abbreviation: PPH, postpartum hemorrhage.

Table 2 Total costs in the cesarean model (base case)

\begin{tabular}{|l|l|l|}
\hline Group of patients & Carbetocin & Oxytocin \\
\hline No PPH & $\$ 271,727$ & $\$ 177,134$ \\
\hline PPH responding to the 1st line of pharmacological treatment & $\$ 1,427.365$ & $\$ 1,332.772$ \\
\hline PPH that respond to additional uterotonics & $\$ 110,906$ & $\$ 16,613$ \\
\hline PPH that respond to the first surgical approach & $\$ 964,178$ & $\$ 869,585$ \\
\hline PPH responding to hysterectomy & $\$ 1,311.469$ & $\$ 1,216.876$ \\
\hline Death & $\$ 231,468$ & $\$ 136,798$ \\
\hline
\end{tabular}

Abbreviation: PPH, postpartum hemorrhage. 
Surveillance System (SIVIGILA, in the Spanish acronym) ${ }^{3}$ and the published literature. Consultation in RIPS and vital statistics was performed using the following diagnostic codes: 0700, 0701, 0702, 0703, 0709, 0712, 0713, 0714, 0719, 0720, 0721, 0730, 0731, 0900, 0901, 0902, 0723, 0622 years 0621 . For the baseline scenario, the mortality data for hemorrhagic complications were taken from SIVIGILA, and a sensitivity analysis was performed considering a minimum of $0 \%$ and a maximum of $3.1 \%$ as reported in the study by Sheldon et al. ${ }^{20}$

The quality-of-life (utility) weights were obtained through a search in the cost-effectiveness analysis (CEA) Registry of Tufts University. Baseline utilities are those related to vaginal and cesarean deliveries. From these, there is a decrease in the quality of life in the population that presents PPH, either because of the requirement of transfusions or because of the need for surgical interventions. The parameters considered in the models are presented in -Table 3.

\section{Cost-effectiveness}

The incremental cost was calculated as the difference between the costs, and the incremental effectiveness as the difference between QALYs obtained when comparing the alternatives. Incremental cost and incremental effectiveness were used to calculate the incremental cost-effectiveness ratio (ICER): The ICER was compared with a cost-effectiveness threshold of 1 gross domestic product (GDP) per capita and 3 GDP per capita. The intervention is considered "costeffective" if the ICER is below 1 GDP per capita and as "potentially cost-effective" if it is less than 3 times GDP per capita

\section{Sensitivity Analysis}

A deterministic and a probabilistic sensitivity analyses were performed, the latter using Monte Carlo simulations.

\section{Results}

\section{Model for Caesarean Section}

The cost-effectiveness ratio of carbetocin compared with oxytocin is presented in - Table 4. Carbetocin is the most effective treatment, and it is less expensive compared with oxytocin, making it the dominant alternative. When considering the outcome of PPH incidence, it is observed that for each hemorrhagic event avoided with the use of carbetocin Col\$ 94,887 are saved.

According to the deterministic sensitivity analysis, at the proposed intervals, the variable that can impact the ICER, so that it is below the threshold, is the proportion of patients presenting with hemorrhagic events with each of the alternatives. Since this variable corresponds to a measure of drug effectiveness, it will not vary significantly until new and more robust evidence is available.

A probabilistic sensitivity analysis was performed with the probability distributions related to the methodology for each of the variables and a Monte Carlo simulation was performed with 1,000 iterations to evaluate the consistency of the results ( - Fig. 3). A willingness to pay threshold of Col\$ $53,090.188$ (3 times the per capita GDP of Col\$ 17,696.729) was established. In all cases, carbetocin was taken as baseline and oxytocin as a comparator. In 52\% of the iterations carbetocin is maintained as a dominant alternative since it is more effective and less costly. In $16.4 \%$ of the iterations carbetocin is dominated by oxytocin. In $16.3 \%$, it is more expensive and more effective, but it is above the willingness to pay threshold, while in $15.3 \%$, it is below the threshold.

The acceptability curve (-Fig. 4) shows that carbetocin proves to be a cost-effective alternative in $70 \%$ of the simulations considering a threshold of $3 \mathrm{GDP} /$ per capita (Col\$ 53,090.188).

\section{Model for Vaginal Delivery}

The cost-effectiveness ratio of carbetocin compared with oxytocin is presented in - Table 5. Carbetocin is the most effective treatment, but it is also costlier compared with oxytocin. The difference in terms of QALYs and incidence of $\mathrm{PPH}$ is small between the two treatments. The ICER is above the cost-effectiveness threshold adopted by Colombia, and when considering the outcome of PPH incidence it is observed that the cost required to avoid additional hemorrhagic events is high.

According to the univariate sensitivity analysis, the variables that can impact the ICER are the proportion of patients presenting with bleeding events in each group as well as the cost of carbetocin.

A probabilistic sensitivity analysis was performed considering the costs and other variables that could become a source of heterogeneity. The probability distributions related in the methodology for each of the variables were taken into account, and a Monte Carlo simulation was performed with 1,000 iterations to evaluate the consistency of the results. The threshold, again, was Col\$ 53,090.188. - Fig. 5 presents the Monte Carlo simulation for incremental analysis. In all cases, carbetocin was taken as the comparator and oxytocin as the baseline. It is observed that in $46.8 \%$ of the iterations, oxytocin remains a dominant alternative since it is more effective and less costly. In $27 \%$ of iterations carbetocin is the dominant alternative. In $18.9 \%$ of the iterations carbetocin is more effective and more expensive than oxytocin but is above the willingness to pay, while at $7.3 \%$ it is below the willingness to pay.

According to the acceptability curve, only carbetocin appears as a cost-effective alternative in $30 \%$ of the simulations considering a threshold of 3 times per capita GDP but it does not substantially increase its likelihood of being costeffective, even with a willingness to pay of Col\$200,000.000.

\section{Discussion}

The results obtained are consistent with those found in other studies. According to the evaluation developed by Moosivand et $\mathrm{al}^{14}$ from the perspective of Iran's health system and society, carbetocin is a dominant alternative compared with 
Table 3 Model parameters

\begin{tabular}{|c|c|c|c|c|c|}
\hline Parameter & Base & Min & Max & Distribution & Source \\
\hline \multicolumn{6}{|l|}{ Vaginal delivery } \\
\hline RR PPH carbetocin & 0.950 & 0.430 & 2.090 & & $\begin{array}{l}\text { Boucher et al. } \\
(2004)^{21}\end{array}$ \\
\hline Probability of PPH in oxytocin group & 0.164 & 0.074 & 0.361 & Beta & $\begin{array}{l}\text { Boucher et al. } \\
(2004)^{21}\end{array}$ \\
\hline Probability of PPH in carbetocin group & 0.156 & 0.071 & 0.343 & Beta & Calculated \\
\hline $\begin{array}{l}\text { Probability of death by hemorrhagic } \\
\text { event }\end{array}$ & 0.003 & 0.000 & 0.031 & Beta & $\begin{array}{l}\text { INS }^{3} \\
\text { Sheldon et al. } \\
(2014)^{20}\end{array}$ \\
\hline $\begin{array}{l}\text { RR use of additional uterotonics } \\
\text { carbetocin }\end{array}$ & 0.930 & 0.440 & 1.940 & & $\begin{array}{l}\text { Boucher et al. } \\
(2004)^{21}\end{array}$ \\
\hline $\begin{array}{l}\text { Probability use of additional uterotonics } \\
\text { oxytocin }\end{array}$ & 0.156 & 0.074 & 0.325 & Beta & $\begin{array}{l}\text { Boucher et al. } \\
(2004)^{21}\end{array}$ \\
\hline $\begin{array}{l}\text { Probability use of additional uterotonics } \\
\text { carbetocin }\end{array}$ & 0.145 & 0.069 & 0.302 & Beta & Calculated \\
\hline \multicolumn{6}{|l|}{ Caesarean section } \\
\hline RR PPH carbetocin & 0.520 & 0.290 & 0.930 & & $\begin{array}{l}\text { Borruto et al. } \\
(2009)^{22}\end{array}$ \\
\hline Probability of PPH in oxytocin group & 0.442 & 0.247 & 0.791 & Beta & $\begin{array}{l}\text { Borruto et al. } \\
(2009)^{22}\end{array}$ \\
\hline Probability of PPH in carbetocin group & 0.230 & 0.128 & 0.411 & Beta & Calculated \\
\hline $\begin{array}{l}\text { Probability of death by hemorrhagic } \\
\text { event }\end{array}$ & 0.008 & 0.000 & 0.031 & Beta & $\begin{array}{l}\text { INS }^{3} \\
\text { Sheldon et al. } \\
(2014)^{20}\end{array}$ \\
\hline $\begin{array}{l}\text { RR use of additional uterotonics } \\
\text { carbetocin }\end{array}$ & 0.700 & 0.510 & 0.980 & & $\begin{array}{l}\text { Borruto et al. } \\
(2009)^{22} \\
\text { Attilakos et al. } \\
(2010)^{23}\end{array}$ \\
\hline $\begin{array}{l}\text { Probability use of additional uterotonics } \\
\text { oxytocin }\end{array}$ & 0.374 & 0.272 & 0.524 & Beta & $\begin{array}{l}\text { Borruto et al. } \\
(2009)^{22} \\
\text { Attilakos et al. } \\
(2010)^{23}\end{array}$ \\
\hline $\begin{array}{l}\text { Probability use of additional uterotonics } \\
\text { carbetocin }\end{array}$ & 0.262 & 0.191 & 0.367 & Beta & Calculated \\
\hline \multicolumn{6}{|l|}{ Vaginal and cesarean delivery } \\
\hline $\begin{array}{l}\text { Requirement for first-line surgical inter- } \\
\text { vention (tamponade and hemostatic } \\
\text { suture) }\end{array}$ & 0.100 & 0.000 & 0.120 & Beta & Experts \\
\hline $\begin{array}{l}\text { Requirement for second line surgical } \\
\text { intervention (hysterectomy) }\end{array}$ & 0.010 & 0.000 & 0.050 & Beta & Experts \\
\hline \multicolumn{6}{|l|}{ Surgical approach } \\
\hline $\begin{array}{l}\text { Proportion of patients undergoing uter- } \\
\text { ine tamponade }\end{array}$ & 0.60 & & & & Experts \\
\hline $\begin{array}{l}\text { Proportion of patients undergoing } \\
\text { hemostatic suture }\end{array}$ & 0.40 & & & & Experts \\
\hline \multicolumn{6}{|c|}{ Frequency of complications of uterine tamponade } \\
\hline Infection & 0.02 & & & & Experts \\
\hline \multicolumn{6}{|c|}{ Frequency of complications of hemostatic suture B-Lynch } \\
\hline Ureteral injury & 0.002 & & & & Experts \\
\hline Bladder injury & 0.001 & & & & Experts \\
\hline Intestinal injury & 0.001 & & & & Experts \\
\hline
\end{tabular}


Table 3 (Continued)

\begin{tabular}{|c|c|c|c|c|c|}
\hline Parameter & Base & Min & Max & Distribution & Source \\
\hline \multicolumn{6}{|l|}{ Frequency of hysterectomy complications } \\
\hline Infection & 0.02 & & & & Experts \\
\hline Ureteral injury & 0.01 & & & & Experts \\
\hline Bladder injury & 0.01 & & & & Experts \\
\hline Intestinal injury & 0.005 & & & & Experts \\
\hline \multicolumn{6}{|l|}{ Utilities } \\
\hline Vaginal delivery utility (Non-PPH) & 0.9997 & 0.9996 & 0.9998 & Triangular & 24 \\
\hline Caesarean section utility (No PPH) & 0.9996 & 0.9995 & 0.9997 & Triangular & 24 \\
\hline $\begin{array}{l}\text { PPH (First Line Treatment) Utility - vaginal } \\
\text { delivery }\end{array}$ & 0.9918 & 0.9913 & 0.9922 & Triangular & 25 \\
\hline $\begin{array}{l}\text { PPH (First Line Treatment) } \\
\text { Utility - Caesarean section }\end{array}$ & 0.9917 & 0.9912 & 0.9921 & Triangular & 25 \\
\hline Disutility by endometritis & 0.0144 & 0.0132 & 0.0155 & Triangular & 25 \\
\hline Disutility due to operative injury & 0.0303 & 0.0280 & 0.0326 & Triangular & 25 \\
\hline Hysterectomy disutility & 0.0334 & 0.0306 & 0.0363 & Triangular & 25 \\
\hline
\end{tabular}

Abbreviation: PPH, postpartum hemorrhage; RR, risk ratio; RR PPH, risk ratio of postpartum hemorrhage.

Table 4 Results of the base case

\begin{tabular}{|l|l|l|l|l|l|}
\hline Cost-utility & QALY & Cost & $\Delta$ QALY & $\Delta$ Cost & ICER (\$/QALY) \\
\hline Carbetocin & 0.9959 & $\$ 461.750$ & 0.00337 & $(\$ 20,116)$ & Dominant \\
\hline Oxytocin & 0.9926 & $\$ 481.866$ & & & \\
\hline Cost-effectiveness & \multicolumn{5}{|l|}{} \\
\hline & Incidence PPH & Cost & Avoided events & \multicolumn{1}{|l|}{$\Delta$ Cost } & $\begin{array}{l}\text { ICER (\$/Avoided } \\
\text { PPH) }\end{array}$ \\
\hline Carbetocin & 0.230 & $\$ 461,750$ & 0.212 & $(\$ 20,116)$ & $(\$ 94,887)$ \\
\hline Oxytocin & 0.442 & $\$ 481,866$ & & & \\
\hline
\end{tabular}

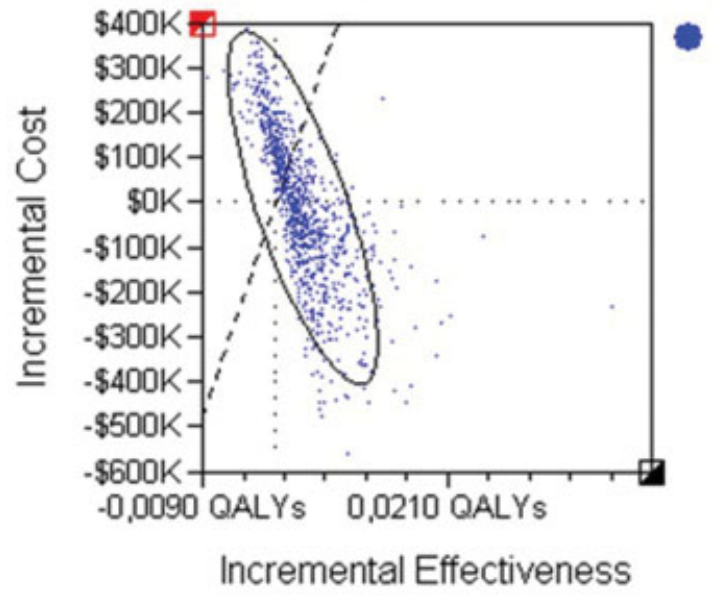

Baseline:'oxytocin, comparator: carbetocina

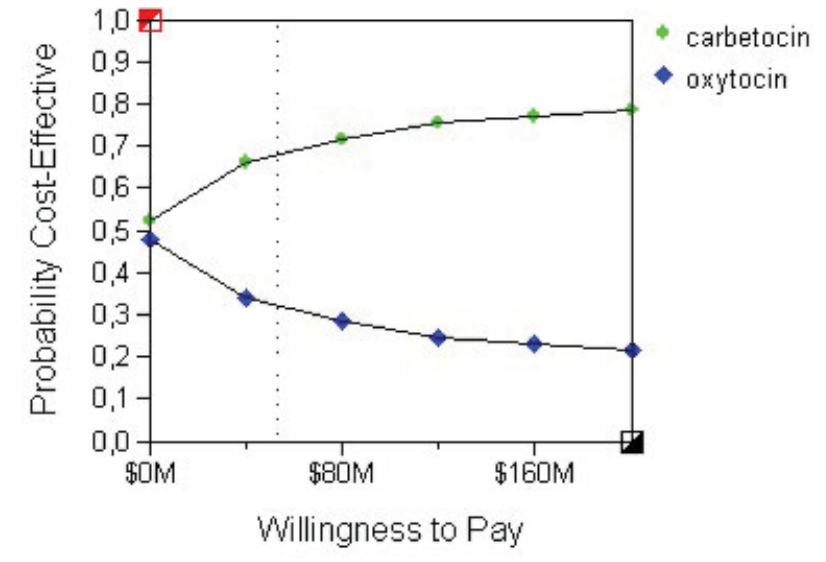

Fig. 4 Acceptability curves.

Fig. 3 Monte Carlo simulations in the cost-effectiveness incremental plane. 
Table 5 Results of the base case

\begin{tabular}{|l|l|l|l|l|l|}
\hline Cost-utility & QALY & Cost & $\Delta$ QALY & $\Delta$ Cost & ICER (\$/QALY) \\
\hline & 0.99800 & $\$ 347,750$ & 0.00009 & $\$ 85,259$ & $\$ 974,790.719$ \\
\hline Carbetocin & 0.99791 & $\$ 262,491$ & & & \\
\hline Oxytocin & \multicolumn{5}{|l|}{} \\
\hline Cost-effectiveness & Incidence PPH & Cost & Avoided events & $\Delta$ Cost & $\begin{array}{l}\text { ICER (\$) Avoided } \\
\text { PPH) }\end{array}$ \\
\hline & & & 0.008 & $\$ 85,259$ & $\$ 10,657.375$ \\
\hline Carbetocin & 0.156 & $\$ 347,750$ & & & \\
\hline Oxytocin & 0.164 & $\$ 262,491$ & & & \\
\hline
\end{tabular}

Abbreviations: ICER, incremental cost-effectiveness ratio; PPH, postpartum hemorrhage; QUALY, quality-adjusted life year.

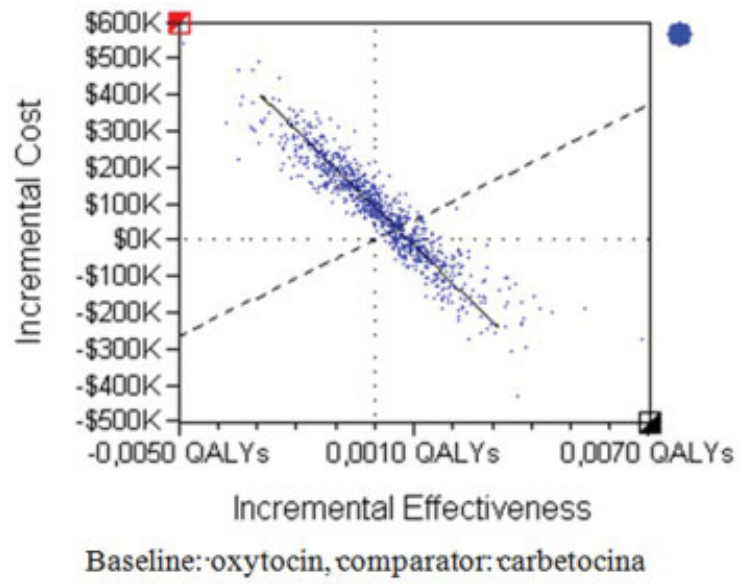

Fig. 5 Monte Carlo simulations in the cost-effectiveness incremental plane.

oxytocin, considering the best possible scenarios (maximum oxytocin price); however, is not cost-effective in other scenarios. In the probabilistic sensitivity analysis, $51.7 \%$ of the iterations were below the willingness to pay threshold for QALY.

In the model of women with at least one risk factor for PPH during vaginal delivery, carbetocin is more effective than oxytocin; however, from the point of view of health system and willingness to pay in the country, it is not a cost-effective alternative. The difference in costs between alternatives is close to Col\$ 80,000 but the difference in terms of QALY is small. According to the literature review, no studies were identified in vaginal delivery, which may be related in part to the fact that carbetocin does not appear as a recommendation of choice in the prevention of PPH due to uterine atony after vaginal delivery. ${ }^{1,4-6,9}$

The limitations of this study are related to the assumptions applied and the lack of studies performed in the highrisk population, both in patients undergoing vaginal delivery and cesarean delivery. The risk of hemorrhage and the use of additional uterotonics differs from one study to the other, in part because of different oxytocin dosing. We used the dosing scheme (and the PPH risk) described by Borruto et $\mathrm{al}^{22}$ and Attilakos et $\mathrm{al}^{23}$ because they included women with at least one risk factor for PPH. In other studies, using even higher doses of oxytocin, ${ }^{26-29}$ the risk reduction with carbetocin was even greater; however, there are differences in the characteristics of the population, particularly related to the level of risk that does not allow to clearly observe the differences between alternatives, so it was preferred to adopt a conservative scenario. Regarding utility values, these were based on international studies, since there are no quality of life studies available in our country, and these may not necessarily reflect the preferences of Colombian patients. In addition, in certain cases, the utility levels referred to in the literature were obtained from a group of experts, so the estimated values may not correspond to real life.

The costing of the different health states and events of the model was performed with the help of clinical experts through the development of a typical case, since there are restrictions to access databases with this type of information and considering that the group of experts is small the estimated resources may not necessarily correspond to those used in the country.

\section{Conclusion}

In this study, the economic model developed for cesarean section shows that carbetocin has greater effectiveness and lower costs, making it a dominant alternative for the prevention of $\mathrm{PPH}$ in high-risk patients. Sensitivity analyses show that within the price range reported in SISMED, it remains either as a dominant alternative, or is below the willingness to pay threshold. The economic model developed for vaginal delivery shows that carbetocin has a cost per additional QALY higher than the acceptable threshold for Colombia.

\section{Contributions}

Gil-Rojas Y., Hernández F., Lasalvia P., Castañeda-Cardona C. and Rosselli D. contributed with the design, data collection, analysis and interpretation of the information, preparation of the preliminary publication, critical review and final approval of the version to be published. 


\section{Conflicts of Interest}

This study was funded by Biopas Laboratories of Colombia. The authors declare that they have no other conflicts of interest.

\section{References}

1 Organización Mundial de la Salud. Recomendaciones de la OMS para la Prevención y el Tratamiento de la Hemorragia Posparto. 2014. http://www.who.int/reproductivehealth/publications/maternal_ perinatal_health/9789241548502/es/. Accessed July 10, 2017

2 Alkema L, Chou D, Hogan D, et al; United Nations Maternal Mortality Estimation Inter-Agency Group collaborators and technical advisory group. Global, regional, and national levels and trends in maternal mortality between 1990 and 2015, with scenario-based projections to 2030: a systematic analysis by the UN Maternal Mortality Estimation Inter-Agency Group. Lancet 2016;387 (10017):462-474. Doi: 10.1016/S0140-6736(15)00838-7

3 de Salud M, Social P. Instituto Nacional de Salud. Sistema Nacional de Vigilancia en Salud Pública: Informes de Evento. 2016. http:// www.ins.gov.co/lineas-de-accion/Subdireccion-Vigilancia/Paginas/informes-de-evento.aspx. Accessed July 11, 2017

4 Ministerio de Salud y Protección Social - Colciencias. Guía de Práctica Clínica para la Prevención, Detección Temprana y Tratamiento del Embarazo, Parto o Puerperio. Guías $N^{\circ} 11-15$. Bogotá: Minsalud; 2013. https://www.minsalud.gov.co/sites/rid/Lists/ BibliotecaDigital/RIDE/INEC/IETS/Gu\%C3\%ADa.completa.Embarazo.Parto.2013.pdf. Accessed July 10, 2017

5 Mavrides E, Allard S, Chandraharan E, et al. Prevention and management of postpartum haemorrhage. BJOG 2017;124(05): e106-e149. Doi: 10.1111/1471-0528.14178

6 Leduc D, Senikas V, Lalonde AB; CLINICAL PRACTICE OBSTETRICS COMMITTEE. Active management of the third stage of labour: prevention and treatment of postpartum hemorrhage. J Obstet Gynaecol Can 2009;31(10):980-993. Doi: 10.1016/S1701-2163 (16)34329-8

7 Instituto de Evaluación Tecnológica en Salud. Manual para la Elaboración de Evaluaciones Económicas en Salud. Bogotá: IETS; 2014

8 Fescina R, De Mucio B, Ortiz E, Jarquin D. Guías para la Atención de las Principales Emergencias Obstétricas. 2012. http://www.clacaidigital.info:8080/xmlui/handle/123456789/782. Accessed July 10, 2017

9 Centro Nacional de Excelencia Tecnológica en Salud. Prevención y Manejo de la Hemorragia Obstetrica en el Primer, Segundo y Tercer Niveles de Atención. México: Secretaria de Salud; 2013. http:// cenetec-difusion.com/gpc-sns/?p=1489. Accessed July 10, 2017

10 Del Angel García G, Garcia-Contreras F, Constantino-Casas P, et al. Economic evaluation of carbetocin for the prevention of uterine atony in patients with risk factors in Mexico. Value Health 2006;9: A254. Doi: 10.1016/S1098-3015(10)63364-5

11 Rueda C, Caceres LA, Caicedo Navas AG. Costo-efectividad de carbetocina en comparación con oxitocina para prevenir hemorragia posparto por atonía uterina en pacientes con factores de riesgo en Colombia. Value Health 2013;16:A709-A710. Doi: 10.1016/j.jval.2013.08.2179

12 Kostyuk A, Akanov A, Almadiyeva A. Clinical effectiveness and cost-effectiveness of carbetocin for the prevention of postpartum hemorrhage. Value Health 2016;19:A173. Doi: 10.1016/j. jval.2016.03.1450

13 van der Nelson HA, Draycott T, Siassakos D, Yau CWH, Hatswell AJ. Carbetocin versus oxytocin for prevention of post-partum haemorrhage at caesarean section in the United Kingdom: An economic impact analysis. Eur J Obstet Gynecol Reprod Biol 2017; 210:286-291. Doi: 10.1016/j.ejogrb.2017.01.004

14 Moosivand A, Foroughi Moghadam M, Khedmati J, Mehralian G. Cost-utility analysis of carbetocin versus oxytocin for managing postpartum hemorrhage. Value Health 2016;19:A177. Doi: 10.1016/j.jval.2016.03.1440

15 Ministerio de Salud y Protección Social. Regulación de Precios de Medicamentos: Listado de Medicamentos con Precio Regulado. Bogotá: Minsalud; 2017. https://www.minsalud.gov.co/salud/ MT/Paginas/medicamentos-regulacion-precios.aspx. Accessed November 15, 2017

16 de Salud M. Instituto de Seguros Sociales. Acuerdo 256 de 2001. Manual de Tarifas de la Entidad Promotora de Salud EPS-ISS. 2001. https://lexsaludcolombia.files.wordpress.com/2010/10/tarifasiss-2001.pdf. Accessed July 10, 2017

17 Departamento Nacional de Planeación. Colombia Compra Eficiente. SECOPI. 2017. https://www.colombiacompra.gov.co/compradores/secop-i. Accessed July 12, 2017

18 Ministerio de Salud y Protección Social. Sistema de Información de Prestaciones de Salud. 2017. http://www.sispro.gov.co/recursosapp/ruaf/pages/rips.aspx. Accessed July 11, 2017

19 Departamento Administrativo Nacional de Estadísticas (DANE). Estadísticas Vitales de Colombia. 2014. http://www.dane.gov.co/ index.php/poblacion-y-demografia/nacimientos-y-defunciones/ 118-demograficas/estadisticas-vitales/2877-defunciones-nofetales. Accessed July 11, 2017

20 Sheldon WR, Blum J, Vogel JP, Souza JP, Gülmezoglu AM, Winikoff B; WHO Multicountry Survey on Maternal and Newborn Health Research Network. Postpartum haemorrhage management, risks, and maternal outcomes: findings from the World Health Organization Multicountry Survey on Maternal and Newborn Health. BJOG 2014;121(Suppl 1):5-13. Doi: 10.1111/1471-0528.12636

21 Boucher M, Nimrod CA, Tawagi GF, Meeker TA, Rennicks White RE, Varin J. Comparison of carbetocin and oxytocin for the prevention of postpartum hemorrhage following vaginal delivery:a doubleblind randomized trial. J Obstet Gynaecol Can 2004;26(05): 481-488. Doi: 10.1016/S1701-2163(16)30659-4

22 Borruto F, Treisser A, Comparetto C. Utilization of carbetocin for prevention of postpartum hemorrhage after cesarean section: a randomized clinical trial. Arch Gynecol Obstet 2009;280(05): 707-712. Doi: 10.1007/s00404-009-0973-8

23 Attilakos G, Psaroudakis D, Ash J, et al. Carbetocin versus oxytocin for the prevention of postpartum haemorrhage following caesarean section: the results of a double-blind randomised trial. BJOG 2010;117(08):929-936. Doi: 10.1111/j.1471-0528.2010.02585.x

24 Plunkett BA, Grobman WA. Routine hepatitis $C$ virus screening in pregnancy: a cost-effectiveness analysis. Am J Obstet Gynecol 2005;192(04):1153-1161. Doi: 10.1016/j.ajog.2004.10.600

25 Fawsitt CG, Bourke J, Greene RA, Everard CM, Murphy A, Lutomski JE. At what price? A cost-effectiveness analysis comparing trial of labour after previous caesarean versus elective repeat caesarean delivery. PLoS One 2013;8(03):e58577. Doi: 10.1371/journal. pone.0058577

26 Dansereau J, Joshi AK, Helewa ME, et al. Double-blind comparison of carbetocin versus oxytocin in prevention of uterine atony after cesarean section. Am J Obstet Gynecol 1999;180(3 Pt 1):670-676. Doi: 10.1016/S0002-9378(99)70271-1

27 Elbohoty AE, Mohammed WE, Sweed M, Bahaa Eldin AM, Nabhan A, Abd-El-Maeboud KH. Randomized controlled trial comparing carbetocin, misoprostol, and oxytocin for the prevention of postpartum hemorrhage following an elective cesarean delivery. Int J Gynaecol Obstet 2016;134(03):324-328. Doi: 10.1016/j.ijgo.2016.01.025

28 Holleboom CA, van Eyck J, Koenen SV, et al. Carbetocin in comparison with oxytocin in several dosing regimens for the prevention of uterine atony after elective caesarean section in the Netherlands. Arch Gynecol Obstet 2013;287(06):1111-1117. Doi: 10.1007/s00404-012-2693-8

29 Taheripanah R, Shoman A, Karimzadeh MA, Zamaniyan M, Malih N. Efficacy of oxytocin versus carbetocin in prevention of postpartum hemorrhage after cesarean section under general anesthesia: a prospective randomized clinical trial. J Matern Fetal Neonatal Med 2017;25:1-6. Doi: 10.1080/14767058.2017.1355907 